\title{
Review \\ Effect of Magnetopriming on Photosynthetic Performance of Plants
}

\author{
Mohammad Sarraf ${ }^{1,+}{ }^{\mathbb{D}}$, Kricelle Mosquera Deamici ${ }^{2}$, Houda Taimourya ${ }^{3}$, Monirul Islam ${ }^{4} \mathbb{D}$, \\ Sunita Kataria ${ }^{5, *}+\mathbb{D}$, Ritesh Kumar Raipuria ${ }^{6}$, Gholamreza Abdi ${ }^{7}$ and Marian Brestic $8,9, *$ (D)
}

1 Department of Horticulture Science, Shiraz Branch, Islamic Azad University, Shiraz 71987-74731, Iran; sarraf.science@gmail.com

2 Faculty of Pharmacy, Federal University of Bahia, Salvador 40170-115, BA, Brazil; kricelledeamici@gmail.com

3 Department of Horticulture, Horticol Complex of Agadir (CHA), Agronomy and Veterinary Institute Hassan II, Agadir 80000, Morocco; houdataimourya@yahoo.com

4 Department of Sustainable Crop Production, Università Cattolica Del Sacro Cuore, Via Emilia Parmense 84, 29122 Piacenza, Italy; monirul.islam@unicatt.it

5 School of Biochemistry, Devi Ahilya Vishwavidyalaya, Khandwa Road, Indore 452001, India

6 ICAR-National Institute for Plant Biotechnology, New Delhi 110012, India; raipuriaritesh@gmail.com

7 Department of Biotechnology, Persian Gulf Research Institute, Persian Gulf University, Bushehr 7516913817, Iran; abdi@pgu.ac.ir

8 Department of Plant Physiology, Slovak University of Agriculture, Nitra, Tr. A. Hlinku 2, 94901 Nitra, Slovakia

9 Department of Botany and Plant Physiology, Faculty of Agrobiology, Food, and Natural Resources, Czech University of Life Sciences Prague, Kamycka 129, 16500 Prague, Czech Republic

* Correspondence: sunita_kataria@yahoo.com (S.K.); marian.brestic@uniag.sk (M.B.)

+ These authors have contributed equally to the work.

Citation: Sarraf, M.; Deamici, K.M.; Taimourya, H.; Islam, M.; Kataria, S.; Raipuria, R.K.; Abdi, G.; Brestic, M. Effect of Magnetopriming on Photosynthetic Performance of Plants. Int. J. Mol. Sci. 2021, 22, 9353. https://doi.org/10.3390/ ijms22179353

Academic Editor: Lars Matthias Voll

Received: 10 July 2021

Accepted: 25 August 2021

Published: 28 August 2021

Publisher's Note: MDPI stays neutral with regard to jurisdictional claims in published maps and institutional affiliations.

Copyright: (C) 2021 by the authors Licensee MDPI, Basel, Switzerland. This article is an open access article distributed under the terms and conditions of the Creative Commons Attribution (CC BY) license (https:/ / creativecommons.org/licenses/by/ $4.0 /)$.

\begin{abstract}
Magnetopriming has emerged as a promising seed-priming method, improving seed vigor plant performance and productivity under both normal and stressed conditions. Various recent reports have demonstrated that improved photosynthesis can lead to higher biomass accumulation and overall crop yield. The major focus of the present review is magnetopriming-based, improved growth parameters, which ultimately favor increased photosynthetic performance. The plants originating from magnetoprimed seeds showed increased plant height, leaf area, fresh weight, thick midrib and minor veins. Similarly, chlorophyll and carotenoid contents, efficiency of PSII, quantum yield of electron transport, stomatal conductance, and activities of carbonic anhydrase (CA), Rubisco and PEP-carboxylase enzymes are enhanced with magnetopriming of the seeds. In addition, a higher fluorescence yield at the J-I-P phase in polyphasic chlorophyll a fluorescence (OJIP) transient curves was observed in plants originating from magnetoprimed seeds. Here, we have presented an overview of available studies supporting the magnetopriming-based improvement of various parameters determining the photosynthetic performance of crop plants, which consequently increases crop yield. Additionally, we suggest the need for more in-depth molecular analysis in the future to shed light upon hidden regulatory mechanisms involved in magnetopriming-based, improved photosynthetic performance.
\end{abstract}

Keywords: biomass; leaf growth; magnetopriming; photosynthetic performance; photosynthetic enzymes; PSII efficiency

\section{Introduction}

Photosynthesis is the process that makes plants diverse organisms on Earth. The primary function of photosynthesis is to convert light energy into chemical energy, which is the key function in plant life and the food chain for animals, but this can be influenced by many environmental factors. Several studies have shown that the photosynthetic process can be affected by high or low light intensity, high or low temperature, heat, salinity, drought, UV-B stress, electrical signals, and geomagnetic field intensity [1-8]. The main 
characteristics of photosynthetic damage indicate lower activity of photosynthetic enzymes, decreased assimilation of carbon dioxide $\left(\mathrm{CO}_{2}\right)$, quantum yield of photosystem II (ФPSII) and increased nonphotochemical quenching (NPQ) [6,7,9-11]. However, photosynthetic light reactions are actively related to the transport of electrons through the chloroplast electron transport chain to ion fluxes of thylakoid membranes, which are particularly charge transferred [12-14].

Among the natural components of our planet, such as water, temperature, climate and electric charges, Earth's magnetic field or geomagnetic field (GMF) is a component that influences many biological processes in plants [15-18]. As a sessile organism, plants show different levels of morphophysiological and molecular responses under different magnetic field (MF) intensities, such as shoot, root and stem elongation, photosynthetic performance, plant nutrient uptake and the expression of several genes associated with photoreceptors $[8,18-20]$. Accordingly, many researchers have used a static magnetic field (SMF) to influence plant growth and development and to reduce cellular oxidative stress under unfavorable environmental conditions. At the present state, for sustainable agriculture, researchers are looking for new environmentally friendly approaches that can contribute to increasing crop yield, but at the same time, they must have a low ecological impact.

In this sense, magnetopriming (exposure of seeds to a MF) is a simple, efficient method having significant worth because it can mitigate abiotic or biotic stress. Various reports have proven that magnetopriming improves seed germination, plant growth, physiology, antioxidant activity, photosynthetic performance and yield under different abiotic stresses, such as drought, salt, UV-B, and arsenic stress [21-24].

Figure 1 illustrates a seed treatment with a magnetic field and various effects of magnetopriming persisting from seed germination to plant maturity. The combined effect of these improved parameters enhances plant growth, biomass, photosynthesis, and yield under nonstress and stressful conditions.

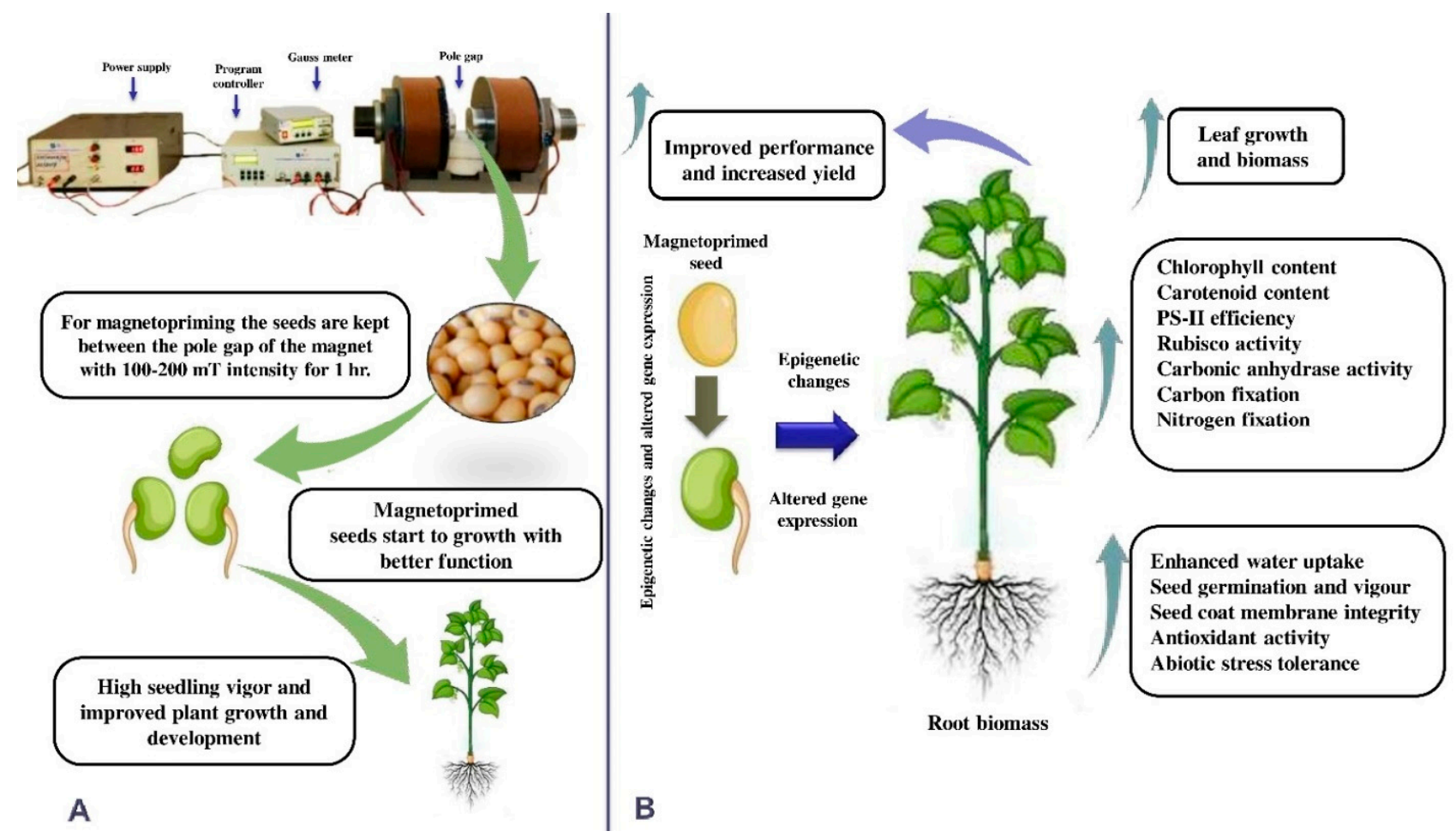

Figure 1. (A) Steps of magnetopriming from seed to plant maturity; (B) various effects of magnetopriming from seed germination to plant maturity contribute to enhance photosynthetic performance under nonstress and stressed conditions. 
However, many other studies have reported that SMF treatment enhances photosystem II (PSII) efficiency, photosynthetic pigments (chlorophyll $a$ and $b$ ), and the performance index, as well as leaf gas exchange performance [19,22,23,25-27]. Hence, the present review aims to present different MF applications and their effects on photosynthetic performance for sustainable agriculture systems.

\section{Effect of a MF on Photosynthetic Pigments}

Exposure to a MF could be useful to enhance plant growth and productivity in addition to overall biomass production, and improvement also affected metabolic substances such as plant photosynthetic pigments. In fact, this better photostimulation and growth can be explained by improving ion uptake and mobilization under a MF [28]. In contrast, plant growth and productivity are generally controlled depending on photosynthetic pigments [29]. Indeed, MFs are known to promote biochemical changes and could be used as a tool to stimulate growth and responses, including photosynthetic pigments such as chlorophyll and carotenoids [30]. A SMF showed a simulative effect on pigment content (carotenoids, chlorophyll $a, b$, and total pigments), whereas carotenoids and chlorophyll $a$ were more affected than chlorophyll $b$ [19]. Chlorophylls are vital pigments that absorb a considerable amount of light energy and perform photosynthetic reactions in plants. Another observation showed that prolonged MF exposure time of a SMF (100 mT for $360 \mathrm{~min}$ ) treatment significantly increased the level of photosynthetic pigments in date palm [31]. Thus, photosynthetic pigment content showed a considerable enhancement in response to a MF at low doses.

The photosynthetic pigments (chlorophyll $a$ and $b$ ) increased obviously in strawberry and tomato plants cultivated in magnetically treated culture medium compared with those cultivated in normal nutrient solution. The increases in chlorophyll a content in strawberry and tomato plants were $345.4 \%$ and $99.1 \%$ compared with the controls, respectively. The percentage of chlorophyll $b$ content in strawberry and tomato plants increased by $255.9 \%$ and $108.4 \%$ compared with the controls, respectively [32].

This is in agreement with earlier findings in a similar experiment under greenhouse conditions, where photosynthesis and chlorophyll content of maize plants increased from magnetically exposed seeds to a SMF of $100 \mathrm{mT}$ for two hours and $200 \mathrm{mT}$ for $1 \mathrm{~h}$, when compared with untreated seeds, under water stress [33]. These results agree with those of Abdul Qados and Hozayn [34], who found increases of $17.46 \%$ and $67.8 \%$ in chlorophyll $a$ and chlorophyll $b$ contents in flax plants, respectively. Moreover, Baghel et al. [27] reported that an enhancement of $126 \%$ in total chlorophyll was recorded in plants that emerged after a $200 \mathrm{mT}$ SMF treatment of soybean seeds compared with the untreated control. Even under salt stress conditions, this enhancement reached $58 \%$ at $50 \mathrm{mM}$ salinity for plants obtained from SMF-treated seeds compared with untreated seeds.

The increases in photosynthetic pigment content in response to a MF were confirmed by several studies for different plants: broad bean, chickpea, tomato, date palm, common bean, sunflower, potato and sugar beet $[25,35-41]$. These significant increases in photosynthetic pigment contents may be attributed to the enhancement in growth promoters (indole acetic acid (IAA)), which increased protein contents [34,36]. In this context, Çelik et al. [42] found a stimulatory effect on photosynthetic pigments as a result of the beneficial effect of a MF on protein synthesis. In addition, Atak et al. [43] explained the increases in all photosynthetic pigments through the increase in cytokine synthesis induced by a MF. In addition, El Sayed [36] found that irrigation of broad bean plants with magnetically treated nutrient solution (MTNS) significantly increased the gibberellic acid (GA3) and kinetin contents compared with the control. A general overview of MFs and their function in photosynthetic pigments is shown in Figure 2. 


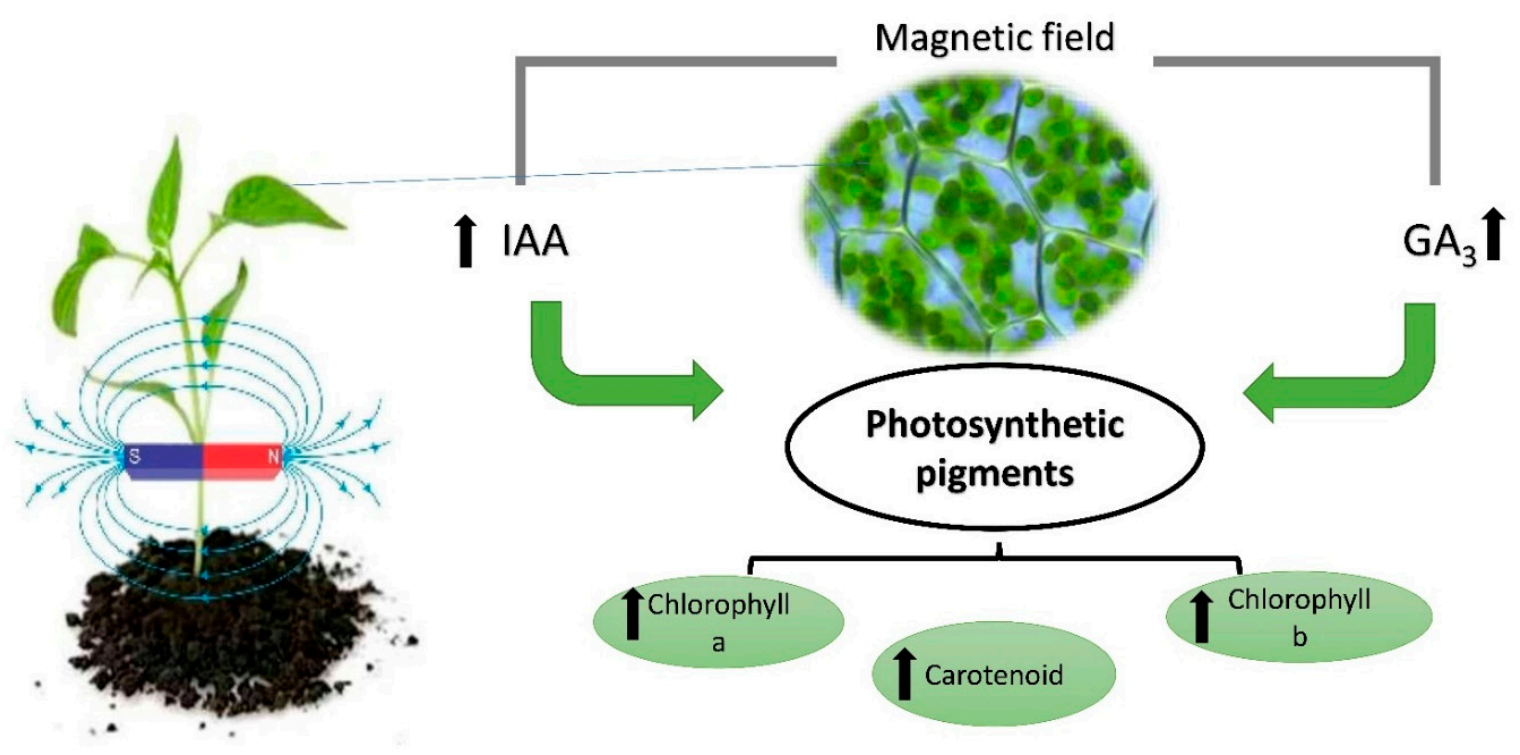

Figure 2. The performance of photosynthetic pigments under the influence of a magnetic field.

The specific effects of the application of a MF on carotenoids and chlorophyll $(a, b)$ and total chlorophyll $(a+b)$ content have been stated for different plant species such as sugar beet, sunflower, soybean, maize, and mung bean under nonstress conditions [25,44-46], as well as in the presence of salt, water, UV-B and cadmium toxicity $[8,21,22,27,47-50]$. Likewise, under drought stress and nonstress conditions, pre-sowing electromagnetic treatments caused improvements in chlorophyll ( $a$ and $b$ ) contents [51]. The MF treatmentinduced enhancement in chlorophyll pigments may possibly be due to the presence of paramagnetic properties of chloroplasts, which may be capable of supporting the rate of seed metabolism [25,52]. Other possible explanations for the increase in pigments are that the magnetic moments of the atoms in MFs are affected and oriented downwards in the field direction. Given that chloroplasts have paramagnetic properties [53], the influence of a MF on plants increases its inner power, which is distributed among the atoms, accelerating plant metabolism [53].

Similarly, carotenoids help plants absorb light energy for use in photosynthesis, since this pigment protects the plants by scavenging reactive oxygen [54], which is known to be affected by magnetic treatment [55]. Conversely, it has been reported that longer exposure decreased the level of photosynthetic pigments in Zea mays L. and Robinia pseudoacacia L. seedlings $[56,57]$. These decreases were linked to the effect of the MF on the reduction in plastids inside the cells [58]. Using MF treatment could be a promising technique for agricultural improvements, but extensive research is required, using different levels of MF doses to determine the optimum dose.

\section{Effect of MF on Chlorophyll Fluorescence}

The kinetic analysis of chlorophyll $a$ fluorescence (Chl F) has become an important tool in basic research on agronomy and plant physiology, representing a new approach to studying the photosynthetic performance of leaves under nonstress and abiotic stresses. The analysis of fluorescence signals is a simple, fast and sensitive method to monitor the changing physiological states of the photosynthetic system [59] that provides accurate information on the status and PSII function and light-harvesting antenna complexes in addition to the transferor and acceptor sides of PSII [12].

Typically, the fluorescence rise in dark-adapted intact leaves after illumination with high actinic light intensity plotted on a logarithmic time scale displaying a polyphasic chlorophyll fluorescence induction curve: O, J, I and P phases (Figure 3). The trajectory of the OJIP curve is a specific point on the induction curve formed by the recorded $\mathrm{Chl}$ F signal [12] and provides some information regarding the functions, conformation and 
structure of the photosynthetic apparatus [59,60]. The JIP test (OJIP) corresponds to the gradual reduction of QA and the primary electron acceptor of PSII [12], and the shape of this curve depends on PSII grouping (L-band) [61] and the balance between electron donation from the oxygen-evolving complex (OEC) to the excited PSII reaction center (P680+) and electron acceptance from the QA-(K-band) [61]. The general behavior of the OJIP curve corresponds to an initial fluorescence Fo (phase O), where the fluorescence transient starts. Then, there are two intermediate steps, FJ and FI (phases J and I, respectively), before it reaches the maximum FM (phase P) [62]. The O-J part corresponds to the closing of some PSII reaction centers due to the reduction of QA to a level between the trapping rate and QA reoxidation rate by $\mathrm{QB}$ and the other part of the electron transfer chain. J-I corresponds to the reduction of plastoquinone (PQ), cytochrome (Cyt b6f), $\mathrm{PC}$ and the secondary electron acceptor $\mathrm{QB}$. The rise in the I-P part is usually attributed to the reduction of some electron transporters, such as ferredoxin, intermediary acceptors and NADP, from the PSI acceptor side [12].

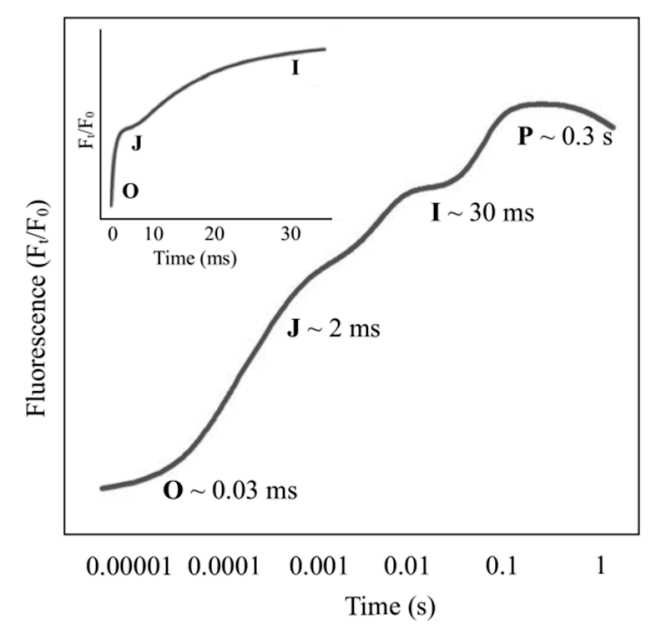

Figure 3. Typical chlorophyll a polyphasic fluorescence curve exhibited by plants by the transient plotted on a logarithmic time scale. The curve plotted on a regular time scale is shown at the bottom, modified from Kalaji et al. [12].

Chl fluorescence analysis also gives an important parameter, the quantum yield, represented by the FV/FM ratio, which is used as the main indicator to evaluate PSII performance [63]. FV corresponds to the variable fluorescence, calculated by the difference between the maximum fluorescence (FM) and minimal fluorescence (F0) [64].

In the case of plant photosynthesis, the observed MF-stimulating effects have been described in regard to the evolution of a radical pair appearing in PSII by Voznyak et al. [65]. The study reported by these authors showed that the MF stimulated fluorescence changes in PSI. The experiments were performed on P-700-enriched complexes isolated from pea chloroplasts. MF-stimulated effects in photosynthetic algae and bacteria were explained by a hypothesis of radical pair recombination in reaction centers [65].

The effect of SMF $200 \mathrm{mT}$ for one hour on polyphasic Chl F transient was studied in soybean trifoliate leaves to evaluate the photochemical efficiency of PSII under nonstress and abiotic stress conditions, such as water, salt, UV-B, and heavy metal toxicity $[8,19,21-24,27,49,50]$. The results of these studies indicated the positive effects of SMF pretreatment on plant growth, photosynthesis, nitrogen metabolism, performance index, PSII efficiency, and yield under nonstress and stressed conditions $[8,19,21-24,27,49,50]$. Electromagnetic treatment was applied at strengths of 100 and $150 \mathrm{mT}$ for $10 \mathrm{~min}$ to corn seeds, which mitigated the drought-induced adverse effects on growth through the improvement of PSII efficiency and other parameters [51]. Relating to the fluorescence yield in dark-adapted trifoliate leaves, the time course plotted on a logarithmic time scale illustrates that the separation of OJIP phases with SMF treatment showed a higher fluorescence yield 
at the I and P phases when the plants were grown under nonstress and abiotic stress conditions (water, salt, UV-B and heavy-metal) compared with the plants obtained from untreated seeds $[8,19,21,22,24,27,49]$. Figure 4 shows the higher fluorescence yield at the $\mathrm{I}$ and $\mathrm{P}$ phases in the third trifoliate leaves of soybean plants that were obtained from SMF-treated seeds (MT) compared with the leaves of plants from untreated (UT) seeds grown under salt stress $(0,25$, and $50 \mathrm{mM} \mathrm{NaCl})$ [27]. The rise in the fluorescence curve after SMF treatment was due to the result of a faster decrease in electron acceptors in the photosynthetic pathway downstream of PSII, particularly $\mathrm{Q}_{\mathrm{A}}$ and plastoquinone [19]. The results of these studies concluded that SMF pretreatment enhanced the tolerance of plants to abiotic stress conditions. SMF pretreatment could ameliorate the inhibition of growth, OJIP test parameters and PSII efficiency as a result of supplemental and ambient UV-B stress in plants $[8,49,50]$. These authors showed that ambient and supplemental or enhanced UV-B stress caused a reduction in the I-P phase of the OJIP curve in third trifoliate leaves of plants that emerged from untreated seeds, while plants that grew from SMF-treated seeds revealed a noteworthy enhancement in the I-P phase under UV-B stress. The IP phase is correlated with electron transfer through PS I [66]. Several performance indices (PIs) have been identified that provide information on the efficiencies of specific electron transport reactions in the thylakoid membrane and the structure and function of PSII [67]. Kataria et al. [8] observed that $\mathrm{Fv} / \mathrm{Fm}$, the maximum quantum yield (efficiency) of PSII, $\triangle \mathrm{V}$ (I-P phase, the amplitude of the comparative contribution of the I-to-P rise for the OJIP transient), $\varphi E 0$, the quantum yield of electron transport, PIABS, performance index at absorption basis and PItotal, total performance index were significantly further improved by SMF-pretreatment than generally used parameters Fv/Fm under ambient UV-B and supplemental UV-B stress, and it was found to be well connected with photosynthetic capability measured as assimilation of $\mathrm{CO}_{2}[68]$.

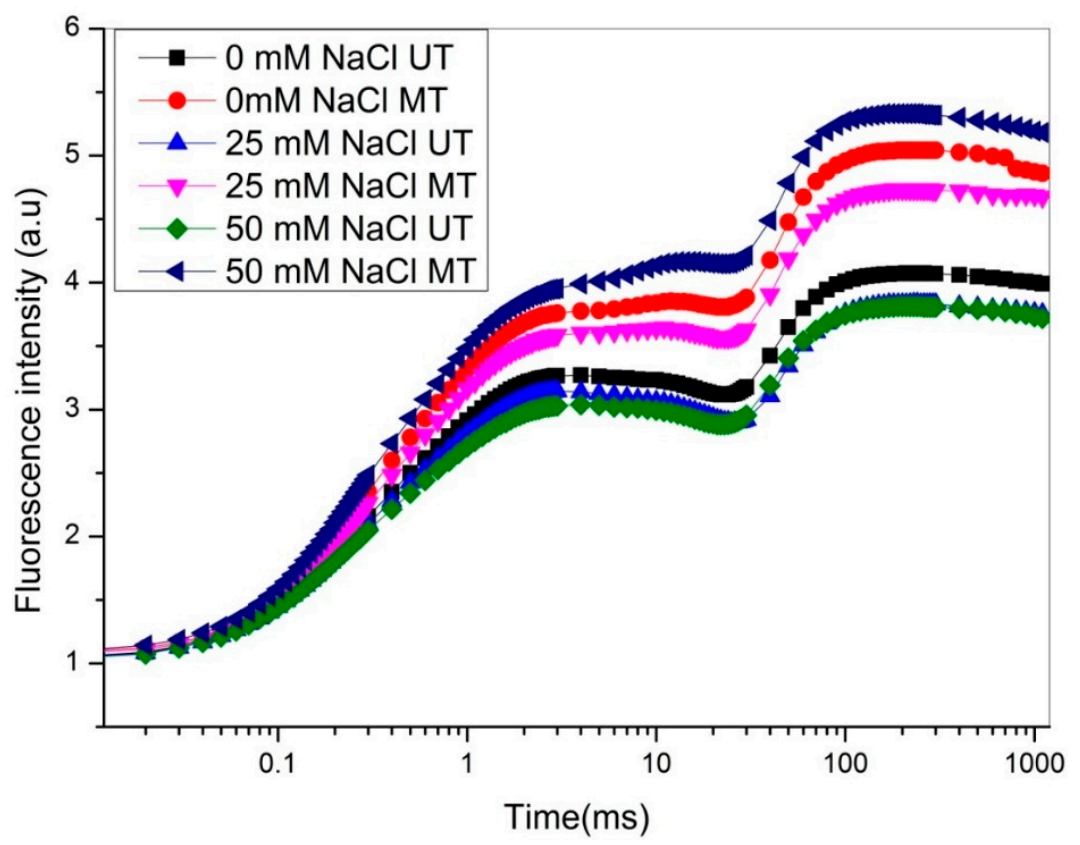

Figure 4. Effect of SMF pretreatment on the typical chlorophyll-a polyphasic fluorescence curve exhibited by third trifoliate leaves of soybean plants under salt stress ( 25 and $50 \mathrm{mM} \mathrm{NaCl})$ by transient plotting on a logarithmic time scale. Modified from Baghel et al. [27]. UT = the plants that emerged from untreated seeds, and MT = the plants that emerged from SMF-pretreated seeds.

Thus, it has been suggested that higher OJIP-test parameters, such as Fv/Fm, Fv / Fo, $\varphi \mathrm{Eo}=\mathrm{ETo} / \mathrm{ABS}, \triangle \mathrm{V}(\mathrm{IP})$, PI total and PIABS, in the plants that emerged after SMF treatment contribute to higher light-harvesting efficiency, and as a result, it caused an increase in the biomass accumulation and uptake of $\mathrm{CO}_{2}$ under nonstress and abiotic stresses, 
such as water, salt, and UV-B stress, thereby enhancing all yield parameters of the crop plants $[8,21,22,27,49,50,69]$. Furthermore, $\mathrm{Chl} a$ fluorescence studies revealed that leaves of SMF-treated plants have higher reducing power with more active reaction centers and higher efficacy of electron transport than untreated plants under nonstress conditions and in the presence of water, salt and ambient UV-B stress [19,21,22,44,49,50,69].

The stress conditions that plants are exposed to are responsible for alterations in their physiology, morphology, physiology and biochemistry, which negatively or positively affect their growth and productivity. Considering the significant effect of MF treatment, particular conditions of time exposure and intensity could cause different effects on the photosynthetic apparatus and $\mathrm{Chl} a$ analysis.

\section{Effect of MFs on Photosynthesis}

Photosynthesis provides the basis for life on Earth by removing $\mathrm{CO}_{2}$ from the atmosphere and releasing oxygen [70]. It consists of a physical-chemical process of converting $\mathrm{CO}_{2}$ and sunlight into energy and organic matter [71,72]. This process can be defined as a reduction reaction based on the light energy captured by the chlorophyll molecules present in plants in which $\mathrm{CO}_{2}$ and water are converted into carbohydrates and oxygen. Photosynthesis is divided into a light phase that takes place in the thylakoid and a dark phase that occurs in the stroma, and both take place in chloroplasts. Light-dependent reactions consist of two main steps, carried out by two main photoactive complexes, PSI and PSII, that carry out electron transport and interact with each other indirectly through a chain electron carrier. Photosynthesis starts at the PSII complex by capturing sunlight, and then electrons transfer to PSI, which are oxidized by light, reducing NADP+ to NADPH and ferredoxin, which are further used in $\mathrm{CO}_{2}$ fixation reactions in the Calvin cycle, also known as the dark phase [73-75].

The photosynthetic process is a very important parameter of plant metabolism that can be used to evaluate the health status of plants since plants are usually very sensitive to environmental changes. Figure 5 represents the plant photosynthetic system with MF action. Numerous authors have investigated the effects of MFs on the metabolism and growth of microalgae and several plant species $[8,27,50,63,76,77]$. The first study on MF effects on plants was conducted by Krylov and Tarakonova [78], and currently MFs are studied as a pretreatment in agriculture for seed priming, aiming to improve seed germination, growth and photosynthesis $[8,23,49,50,69,79,80]$. Photosynthetic organisms, such as cyanobacteria, algae and plants, are fundamental to life on Earth because of the conversion of solar energy, water and $\mathrm{CO}_{2}$ to chemical energy [71]. To date, several studies have been carried out to evaluate the response of various plant species under different ranges of MF intensities. Among these studies, Pittman [81] observed that a MF of relatively low intensity may possibly be effective in stimulating or initiating plant growth responses, and afterward, other studies showed different effects also with high intensities.

Shine et al. [19] investigated the effect of a SMF of 0-300 $\mathrm{mT}$ on soybean seeds for 30, 60 and $90 \mathrm{~min}$. The results demonstrated that a MF increased germination-related parameters, such as speed of germination, water uptake, seedling length, biomass accumulation and vigor indices. As a more effective treatment, MF application at 200 and $150 \mathrm{mT}$ for one hour promoted growth, leaf protein content and photosynthetic efficiency. Anand et al. [33] evaluated the effects of a SMF on maize plants in a similar experiment under field conditions and showed that a SMF of $200 \mathrm{mT}$ for one hour and $100 \mathrm{mT}$ for two hours was sufficient to increase photosynthesis and $\mathrm{Chl}$ content when the maize plants were compared with the control under irrigated and mild-stress conditions. Other studies have demonstrated that SMF pretreatment causes an increase in the rate of photosynthesis and stomatal conductance $[8,22,49,69,82,83]$, as well as the biomass accumulation in crop plants under abiotic stresses, such as salt, water, arsenic and cadmium toxicity and ambient and enhanced UV-B stress $[8,21,22,24,27,48-50]$. Thus, pre-sowing SMF treatment can be effectively used to alleviate the adverse effects of abiotic stress in crop plants by increasing the photosynthetic performance of the plants. 


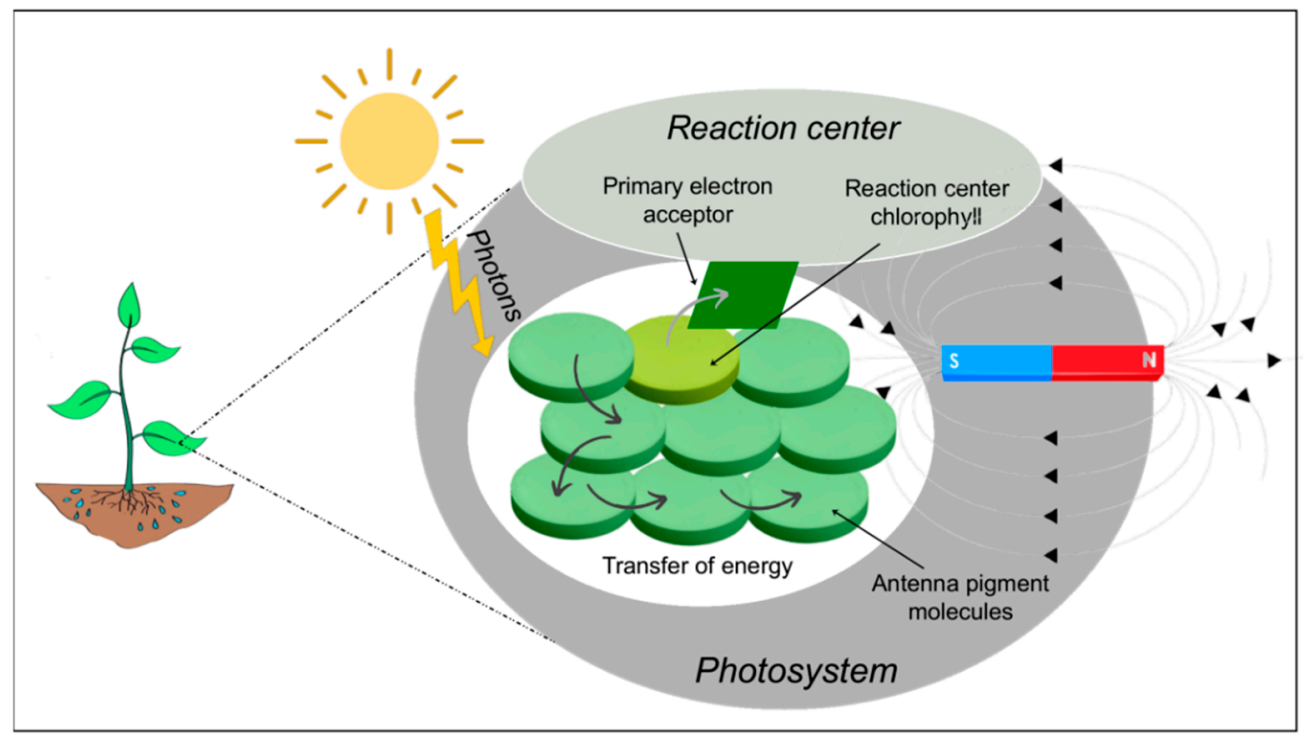

Figure 5. Magnetic field action on the plant photosynthetic system.

\section{Effect of MFs on Photosynthetic Enzymes}

The photosynthetic performance of any plant is also dependent on the activity of photosynthetic enzymes, such as CA, Rubisco, and PEP carboxylase, along with the efficiency of PSI and PSII. It is a well-known fact that efficient photosynthesis leads to higher biomass accumulation, which primarily determines overall plant performance, including yield, under normal and stressed conditions [84]. Seed priming with MF treatment has been proven to improve the photosynthetic performance of various crop species through increased efficiency of PSI, PSII, OJIP test parameters and gas exchange parameters in nonstress and abiotic stress conditions $[8,15,21-23,27,33,49,69]$. Whether this improved photosynthetic performance of plants by magnetopriming is due to improved activities of enzymes related to photosynthesis has not been explored much, but a few reports are available as a proof-of-concept in this regard. Total protein gel profiling of trifoliate leaves originating from unprimed and SMF-primed soybean seeds was performed by Shine et al. [19]. The SDS gel profile showed greater band intensities of the Rubisco large subunit $(53 \mathrm{kDa})$ and small subunit $(14 \mathrm{kDa})$ in SMF-treated samples than in untreated samples [19]. Similarly, Patel [85] also found that the expression of genes related to the Rubisco large subunit, PEP carboxylase and CA enzymes was higher in the leaves of plants from SMF-primed seeds compared with unprimed seeds. The CA enzyme is known to be involved in the first step of $\mathrm{C}_{4}$ photosynthesis, which is the conversion of $\mathrm{CO}_{2}$ molecules to $\mathrm{HCO}_{3}$ via hydration. Recently, it has been shown that SMF priming of soybean and maize seeds enhanced the CA activity in the leaves under nonstress and ambient UV-B stress conditions with respect to their unprimed control plants, which helped alleviate the detrimental effects of ambient UV-B stress [50]. Likewise, the activity of CA and PEP carboxylase activity were significantly increased by magnetopriming under nonstress conditions in maize plants [85]. Thus, the results from the literature suggest that the linear flow of electrons beyond PSII may be increased by magnetopriming, as evident by the $\mathrm{Chl} a$ fluorescence data, which leads to a greater proportion of electrons available for the Calvin cycle, it may be accountable for magnetopriming enhanced expression and activity of photosynthetic enzymes such as Rubisco, CA and PEP-carboxylase.

\section{Effects of Magnetic Field Treatment on Leaf Features}

Leaf morphological features (leaf length, width, area, shape, and venation network) and anatomical features (mesophyll cell and bundle sheath cell organization and vasculature) determine the quantity of light interception and photosynthetic capacity [86]. Similarly, leaf venation provides mechanical support along with mobilization of pho- 
tosynthates from source to sink $[86,87]$. Whether magnetopriming of seeds alters leaf features to improve photosynthesis has not been explored. In this regard, synchrotronbased, phase-sensitive imaging revealed that magnetopriming of soybean seeds ( $200 \mathrm{mT}$ for $1 \mathrm{~h}$ ) increased the thickness of the midrib, minor veins and area of third trifoliate leaves compared with unprimed leaves $[24,87,88]$. Furthermore, midrib thickness and area enhancement led to an increased rate of water uptake, photosynthesis, and stomatal conductance. These altered features of leaves by magnetopriming have not been explored much, and plant researchers working in this area should explore these opportunities, which will further improve our understanding regarding the mechanisms involved in magnetopriming-induced improvement of crop photosynthetic performance.

\section{Effect of MFs on the Yield of Plants}

The beneficial effect of magnetic treatment on plant yield has been widely demonstrated in many plant species (Table 1). In spring maize, incremental effects of magnetic field treatment of water have been noticed in plant yield [89]. Seed magnetopriming not only alleviated salt stress effects but also resulted in an outstanding boost in yield attributes in saline and non-saline conditions [22,27]. Seed exposure to a SMF has the potential to increase crop production per unit area of land without having any negative effects on any environmental component $[22,27,69]$. Static and pulsed MF treatment was found to increase the productivity of cherry tomatoes under a controlled environment [90]. The magnetopriming of soybean seeds allowed SMF-treated plants to overcome the harmful effects of water, salt, and UV-B stress on growth, biomass accumulation and yield in terms of the number of seeds and pods per plant, weight of seeds and pods per plant, and harvest index $[21,27,49,69]$.

Table 1. A summary of the effect of magnetic fields on plants to alleviate different abiotic stresses.

\begin{tabular}{|c|c|c|c|c|}
\hline MF Optimal Intensity & Stress Condition & Plant Species & Effects & References \\
\hline $200 \mathrm{mT}$ & Water stress & Glycine $\max \mathrm{L}$. & $\begin{array}{l}\text { Increased the plant growth attributes, } \\
\text { photosynthetic performance, biomass } \\
\text { accumulation, and crop yield }\end{array}$ & [21] \\
\hline $200 \mathrm{mT}$ & Salinity stress & Glycine max L. & $\begin{array}{l}\text { An enhancement of growth attributes, } \\
\text { photosynthetic performance and crop yield }\end{array}$ & [27] \\
\hline $200 \mathrm{mT}$ & Salinity stress & Zea mays L. & $\begin{array}{l}\text { Enhanced seedling vigor growth parameters, } \\
\text { PSII photochemistry (Fv / Fm) and crop yield }\end{array}$ & [22] \\
\hline $200 \mathrm{mT}$ & $\begin{array}{l}\text { Arsenic (As) toxicity } \\
\text { tolerance }\end{array}$ & Glycine max L. & $\begin{array}{c}\text { Reduced As toxicity and increased plant } \\
\text { growth parameters with noticeable increase } \\
\text { in water uptake, stomatal conductance, PSII } \\
\text { performance and photosynthesis }\end{array}$ & [24] \\
\hline $200 \mathrm{mT}$ & $\begin{array}{l}\text { Ultraviolet-B } \\
\text { radiation tolerant }\end{array}$ & Glycine max L. & $\begin{array}{l}\text { Increased photosynthetic performance along } \\
\text { with higher crop yield, decreased } \mathrm{H}_{2} \mathrm{O}_{2} \\
\text { content and antioxidant levels }\end{array}$ & [8] \\
\hline $200 \mathrm{mT}$ & $\begin{array}{l}\text { Ultraviolet-B } \\
\text { radiation tolerant }\end{array}$ & Glycine $\max \mathrm{L}$. & $\begin{array}{l}\text { Significant enhancement in growth } \\
\text { parameters and higher expression of genes } \\
\text { related to amylase, NR and NOS enzymes }\end{array}$ & [91] \\
\hline $50 \mathrm{mT}$ & Salinity stress & Triticum aestivum $\mathrm{L}$. & $\begin{array}{l}\text { Increased total chlorophyll contents and } \\
\mathrm{Na}^{+} / \mathrm{K}^{+} \text {ratio and growth attributes }\end{array}$ & [84] \\
\hline $100 \mathrm{mT}$ & Salinity stress & Cicer arietinum $\mathrm{L}$. & $\begin{array}{l}\text { Enhanced physiological traits, antioxidant } \\
\text { activity and } \mathrm{Na}^{+} / \mathrm{K}^{+} \text {ratio, overall growth } \\
\text { attributes }\end{array}$ & [92] \\
\hline $136 \mathrm{mT}$ & Drought stress & $\begin{array}{l}\text { Pisum sativum } \mathrm{L} \text {. } \\
\text { Apium graveolens } \mathrm{L} \text {. }\end{array}$ & $\begin{array}{l}\text { Increased yield and physiological parameters } \\
\text { along with } \mathrm{Na}^{+} / \mathrm{K}^{+} \text {ratio }\end{array}$ & [93] \\
\hline $150 \mathrm{mT}$ & Drought stress & Zea mays L. & $\begin{array}{c}\text { An enhancement of chlorophyll } a \text { and } b \\
\text { pigments, leaf water potential, stomatal } \\
\text { conductance and decreased total proline } \\
\text { contents }\end{array}$ & [51] \\
\hline
\end{tabular}




\section{Conclusions and Future Perspectives}

Photosynthesis is considered a major determinant of crop productivity. Globally, the plant scientific community is continuously making efforts toward improving the photosynthetic performance of crop species. Genetic manipulations of various processes of photosynthesis alone cannot bring a drastic increase in crop yield in an unpredictable changing global environment. Magnetopriming of seeds has emerged as one of the simplest, efficient, noninvasive methods to improve seed vigor. Magnetoprimed seeds germinate faster and perform well under normal and stressed conditions. In this review, we have discussed the effects of magnetopriming on various photosynthetic parameters of plants. Photosynthesis is a multistep process, and the effect of magnetopriming on these steps has not been explored much thus far. However, magnetopriming-induced increases in photosynthetic pigments, J-I-P test parameters, activities of photosynthetic enzymes, biomass accumulation and rate of photosynthesis and stomatal conductance are evident from the literature. Leaf architectural features dominantly regulate the photosynthetic efficiency of plants. These features are affected by magnetopriming and could not be explored thoroughly. This has the potential to increase crop production through higher photosynthetic activities even under abiotic stress conditions without having any damaging effect on environmental components. Currently, whole transcriptome, proteome and metabolome analyses have become easy to perform, which could provide an idea about the genes and proteins that come into play after magnetopriming and improve the photosynthetic performance of plants. The global population is growing rapidly, and crop yield should also be increased proportionally to match the demand for food. In this scenario, magnetopriming is an easy option to improve crop performance and yield even under stress conditions; however, there is still a need for further research on the effect of magnetopriming on photosynthetic performance under biotic stresses, and detailed studies are required on the effect of MFs on photosynthetic enzyme activities. Additionally, detailed studies on magnetopriming-induced molecular signatures will pave the way to exploit this technology for improved crop performance globally.

Author Contributions: M.S. and S.K. conceived the concept. M.S., S.K., K.M.D., M.I., H.T., R.K.R., and G.A. provided an outline, drafted the manuscript and produced the graphic models and table. S.K., M.B., M.S., and K.M.D. edited the manuscript. M.S., S.K., M.I., G.A., and M.B. revised and responded to reviewer comments. All authors have read and agreed to the published version of the manuscript.

Funding: This research received no external funding.

Acknowledgments: This collaborative study received no external funding.

Conflicts of Interest: The authors declare no conflict of interest.

\section{References}

1. Kanervo, E.; Tasaka, Y.; Murata, N.; Aro, E.-M. Membrane lipid unsaturation modulates processing of the photosystem II reaction-center protein D1 at low temperatures. Plant Physiol. 1997, 114, 841-849. [CrossRef] [PubMed]

2. Quiles, M.J. Stimulation of chlororespiration by heat and high light intensity in oat plants. Plant Cell Environ. 2006, 29, 1463-1470. [CrossRef] [PubMed]

3. Battisti, D.S.; Naylor, R.L. Historical warnings of future food insecurity with unprecedented seasonal heat. Science 2009, 323, 240-244. [CrossRef] [PubMed]

4. Lawlor, D.W.; Tezara, W. Causes of decreased photosynthetic rate and metabolic capacity in water-deficient leaf cells: A critical evaluation of mechanisms and integration of processes. Ann. Bot. 2009, 103, 561-579. [CrossRef]

5. Kalaji, H.M.; Carpentier, R.; Allakhverdiev, S.I.; Bosa, K. Fluorescence parameters as early indicators of light stress in barley. J. Photochem. Photobiol. B Biol. 2012, 112, 1-6. [CrossRef]

6. Murata, N.; Allakhverdiev, S.I.; Nishiyama, Y. The mechanism of photoinhibition in vivo: Re-evaluation of the roles of catalase, $\alpha$-tocopherol, non-photochemical quenching, and electron transport. Biochim. Biophys. Acta (BBA)-Bioenerg. 2012, 1817, 1127-1133. [CrossRef]

7. Urban, J.; Ingwers, M.W.; McGuire, M.A.; Teskey, R.O. Increase in leaf temperature opens stomata and decouples net photosynthesis from stomatal conductance in Pinus taeda and Populus deltoides x nigra. J. Exp. Bot. 2017, 68, 1757-1767. [CrossRef] [PubMed] 
8. Kataria, S.; Jain, M.; Rastogi, A.; Brestic, M. Static magnetic field treatment enhanced photosynthetic performance in soybean under supplemental ultraviolet-B radiation. Photosynth. Res. 2021. [CrossRef] [PubMed]

9. Zivcak, M.; Brestic, M.; Balatova, Z.; Drevenakova, P.; Olsovska, K.; Kalaji, H.M.; Yang, X.; Allakhverdiev, S.I. Photosynthetic electron transport and specific photoprotective responses in wheat leaves under drought stress. Photosynth. Res. 2013, 117, 529-546. [CrossRef] [PubMed]

10. Alte, F.; Stengel, A.; Benz, J.P.; Petersen, E.; Soll, J.; Groll, M.; Bölter, B. Ferredoxin: NADPH oxidoreductase is recruited to thylakoids by binding to a polyproline type II helix in a pH-dependent manner. Proc. Natl. Acad. Sci. USA 2010, 107, 19260-19265. [CrossRef]

11. Benz, J.P.; Lintala, M.; Soll, J.; Mulo, P.; Bölter, B. A new concept for ferredoxin-NADP (H) oxidoreductase binding to plant thylakoids. Trends Plant Sci. 2010, 15, 608-613. [CrossRef] [PubMed]

12. Kalaji, H.M.; Jajoo, A.; Oukarroum, A.; Brestic, M.; Zivcak, M.; Samborska, I.A.; Cetner, M.D.; Łukasik, I.; Goltsev, V.; Ladle, R.J. Chlorophyll a fluorescence as a tool to monitor physiological status of plants under abiotic stress conditions. Acta Physiol. Plant. 2016, 38, 102. [CrossRef]

13. Cruz, J.A.; Avenson, T.J.; Kanazawa, A.; Takizawa, K.; Edwards, G.E.; Kramer, D.M. Plasticity in light reactions of photosynthesis for energy production and photoprotection. J. Exp. Bot. 2005, 56, 395-406. [CrossRef] [PubMed]

14. Price, C.; Williams, E.; Elhalel, G.; Sentman, D. Natural ELF fields in the atmosphere and in living organisms. Int. J. Biometeorol. 2021, 65, 85-92. [CrossRef] [PubMed]

15. Sarraf, M.; Kataria, S.; Taimourya, H.; Santos, L.O.; Menegatti, R.D.; Jain, M.; Ihtisham, M.; Liu, S. Magnetic field (MF) applications in plants: An overview. Plants 2020, 9, 1139. [CrossRef]

16. Maffei, M.E. Magnetic field effects on plant growth, development, and evolution. Front. Plant Sci. 2014, 5, 445. [CrossRef]

17. Islam, M.; Vigani, G.; Maffei, M.E. The Geomagnetic Field (GMF) Modulates Nutrient Status and Lipid Metabolism during Arabidopsis thaliana Plant Development. Plants 2020, 9, 1729. [CrossRef]

18. Islam, M.; Maffei, M.E.; Vigani, G. The geomagnetic field is a contributing factor for an efficient iron uptake in Arabidopsis thaliana. Front. Plant Sci. 2020, 11, 325. [CrossRef]

19. Shine, M.; Guruprasad, K.; Anand, A. Enhancement of germination, growth, and photosynthesis in soybean by pre-treatment of seeds with magnetic field. Bioelectromagnetics 2011, 32, 474-484. [CrossRef]

20. Agliassa, C.; Narayana, R.; Christie, J.M.; Maffei, M.E. Geomagnetic field impacts on cryptochrome and phytochrome signaling. J. Photochem. Photobiol. B Biol. 2018, 185, 32-40. [CrossRef] [PubMed]

21. Baghel, L.; Kataria, S.; Guruprasad, K. Effect of static magnetic field pretreatment on growth, photosynthetic performance and yield of soybean under water stress. Photosynthetica 2018, 56, 718-730. [CrossRef]

22. Baghel, L.; Kataria, S.; Jain, M. Mitigation of adverse effects of salt stress on germination, growth, photosynthetic efficiency and yield in maize (Zea mays L.) through magnetopriming. Acta Agrobot. 2019, 72, 1757. [CrossRef]

23. Kataria, S.; Baghel, L.; Jain, M.; Guruprasad, K. Magnetopriming regulates antioxidant defense system in soybean against salt stress. Biocatal. Agric. Biotechnol. 2019, 18, 101090. [CrossRef]

24. Fatima, A.; Kataria, S.; Prajapati, R.; Jain, M.; Agrawal, A.K.; Singh, B.; Kashyap, Y.; Tripathi, D.K.; Singh, V.P.; Gadre, R. Magnetopriming effects on arsenic stress-induced morphological and physiological variations in soybean involving synchrotron imaging. Physiol. Plant. 2020, 173, 88-99. [CrossRef]

25. Rochalska, M. Influence of frequent magnetic field on chlorophyll content in leaves of sugar beet plants. Nukleonika 2005, 50, 25-28.

26. Kataria, S.; Baghel, L.; Guruprasad, K. Pre-treatment of seeds with static magnetic field improves germination and early growth characteristics under salt stress in maize and soybean. Biocatal. Agric. Biotechnol. 2017, 10, 83-90. [CrossRef]

27. Baghel, L.; Kataria, S.; Guruprasad, K.N. Static magnetic field treatment of seeds improves carbon and nitrogen metabolism under salinity stress in soybean. Bioelectromagnetics 2016, 37, 455-470. [CrossRef] [PubMed]

28. Taimourya, H.; Oussible, M.; Baamal, L.; Bourarach, E.; Hassanain, N.; Masmoudi, L.; El-Harif, A. Effect of magnetically treated water on strawberry plants (Fragaria $\times$ ananassa Duch.) in the northwest of Morocco. In Proceedings of the VIII International Scientific Agriculture Symposium, "Agrosym 2017", Jahorina, Bosnia and Herzegovina, 5-8 October 2017; pp. $382-387$.

29. Carbonell, M.V.; Martinez, E.; Amaya, J.M. Stimulation of germination in rice (Oryza sativa L.) by a static magnetic field. Electro-Magn. 2000, 19, 121-128. [CrossRef]

30. Taimourya, H.; Oussible, M.; Baamal, L.; Bourarach, E.H.; Hassanain, N.; Masmoudi, L.; El Harif, A. Magnetically treated irrigation water improves the production and the fruit quality of strawberry plants (Fragaria $\times$ ananassa Duch.) in the northwest of Morocco. J. Agric. Sci. Technol. 2018, 8, 145-156. [CrossRef]

31. Dhawi, F.; Al-Khayri, J.M. Magnetic fields induce changes in photosynthetic pigments content in date palm (Phoenix dactylifera L.) seedlings. Open Agric. J. 2009, 3, 1-5. [CrossRef]

32. Taimourya, H.; Oussible, M.; Baamal, L.; Harif, A.; Zaid, E.; Guedira, A.; Smouni, A. Magnetic Treatment of Culture Medium Enhance Growth and Minerals Uptake of Strawberry (Fragaria $\times$ ananassa Duch.) and Tomato (Solanum lycopersicum) in Fe Deficiency Conditions. Int. J. Sci. Eng. Res. 2017, 8, 1414-1436.

33. Anand, A.; Nagarajan, S.; Verma, A.; Joshi, D.; Pathak, P.; Bhardwaj, J. Pre-treatment of seeds with static magnetic field ameliorates soil water stress in seedlings of maize (Zea mays L.). Indian J. Biochem. Biol. 2012, 49, 63-70. Available online: http:/ /nopr.niscair.res.in/handle/123456789/13593 (accessed on 1 February 2021). 
34. Abdul Qados, A.; Hozayn, M. Response of growth, yield, yield components and some chemical constituents of flax for irrigation with magnetized and tap water. World Appl. Sci. J. 2010, 8, 630-634.

35. De Souza, A.; Garcí, D.; Sueiro, L.; Gilart, F.; Porras, E.; Licea, L. Pre-sowing magnetic treatments of tomato seeds increase the growth and yield of plants. Bioelectromagnetics 2006, 27, 247-257. [CrossRef]

36. El Sayed, H.E.S.A. Impact of magnetic water irrigation for improve the growth, chemical composition and yield production of broad bean (Vicia faba L.) plant. J. Exp. Agric. Int. 2014, 4, 476-496. [CrossRef]

37. Oldacay, S.; Erdem, G. Evaluation of Chlorophyll Contents and Peroxidase Activities in Helianthus annuus Genotypes Exposed to Radiation and Magnetic Fields. J. Appl. Sci. 2002, 2, 934-937. [CrossRef]

38. Racuciu, M.; Miclaus, S.; Creanga, D. The response of plant tissues to magnetic fluid and electromagnetic exposure. Rom. J. Biophys. 2009, 19, 73-83. Available online: https: / / www.rjb.ro/articles/229/art07Racuciu.pdf (accessed on 1 March 2021).

39. Rakosy-Tican, L.; Aurori, C.; Morariu, V. Influence of near null magnetic field on in vitro growth of potato and wild Solanum species. Bioelectromagnetics 2005, 26, 548-557. [CrossRef]

40. Tahir, N.A.; Karim, H.F.H. Impact of magnetic application on the parameters related to growth of chickpea (Cicer arietinum L.). Jordan J. Biol. Sci. 2010, 3, 175-184.

41. Voica, C.; Polescu, L.; Lazar, D. The influence of the magnetic fluids on some physiological processes in Phaseolus vulgaris. Rev. Roum. Biol. 2003, 48, 9-15.

42. Çelik, Ö.; Atak, Ç.; Rzakulieva, A. Stimulation of rapid regeneration by a magnetic field in paulownia node cultures. J. Cent. Eur. Agric. 2008, 9, 297-304. Available online: https://jcea.agr.hr/en/issues/article/525 (accessed on 20 March 2021).

43. Atak, Ç.; Yurttaş, B.; Yalçın, S.; Mutlu, D.; Rzakoulieva, A.; Danilov, V. Effects of Magnetic Field on soybean (Glycine max. L. Merrill) seeds. Com. JINR. Dubna 1997. 1-13. Available online: https://hdl.handle.net/11413/2851 (accessed on 20 March 2021).

44. Shine, M.; Guruprasad, K. Impact of pre-sowing magnetic field exposure of seeds to stationary magnetic field on growth, reactive oxygen species and photosynthesis of maize under field conditions. Acta Physiol. Plant. 2012, 34, 255-265. [CrossRef]

45. Turker, M.; Temirci, C.; Battal, P.; Erez, M.E. The effects of an artificial and static magnetic field on plant growth, chlorophyll and phytohormone levels in maize and sunflower plants. Phyton. Ann. Rei Bot. 2007, 46, 271-284. Available online: https: //www.zobodat.at/pdf/PHY_46_2_0271-0284.pdf (accessed on 2 February 2021).

46. Radhakrishnan, R.; Kumari, B.D.R. Influence of pulsed magnetic field on soybean (Glycine max L.) seed germination, seedling growth and soil microbial population. Indian J. Biochem. Biophys. 2013, 50, 312-317. Available online: http://nopr.niscair.res.in/ bitstream/123456789/20879/1/IJBB\%2050(4)\%20312-317.pdf (accessed on 2 July 2020). [PubMed]

47. Asghar, T.; Iqbal, M.; Jamil, Y.; Nisar, J.; Shahid, M. Comparison of HeNe laser and sinusoidal non-uniform magnetic field seed pre-sowing treatment effect on Glycine max (Var 90-I) germination, growth and yield. J. Photochem. Photobiol. B Biol. 2017, 166, 212-219. [CrossRef]

48. Chen, Y.-P.; Li, R.; He, J.-M. Magnetic field can alleviate toxicological effect induced by cadmium in mungbean seedlings. Ecotoxicology 2011, 20, 760-769. [CrossRef]

49. Kataria, S.; Baghel, L.; Guruprasad, K. Alleviation of adverse effects of ambient UV stress on growth and some potential physiological attributes in soybean (Glycine max) by seed pre-treatment with static magnetic field. J. Plant Growth Regul. 2017, 36, 550-565. [CrossRef]

50. Kataria, S.; Rastogi, A.; Bele, A.; Jain, M. Role of nitric oxide and reactive oxygen species in static magnetic field pre-treatment induced tolerance to ambient UV-B stress in soybean. Physiol. Mol. Biol. Plants 2020, 26, 931-945. [CrossRef] [PubMed]

51. Javed, N.; Ashraf, M.; Akram, N.A.; Al-Qurainy, F. Alleviation of adverse effects of drought stress on growth and some potential physiological attributes in maize (Zea mays L.) by seed electromagnetic treatment. Photochem. Photobiol. 2011, 87, 1354-1362. [CrossRef] [PubMed]

52. Aladjadjiyan, A.; Ylieva, T. Influence of stationary magnetic field on the early stages of the development of tobacco seeds (Nicotiana tabacum L.). J. Cent. Eur. Agric. 2003, 4, 131-138. Available online: https://jcea.agr.hr/en/issues/article/124 (accessed on 1 March 2021).

53. Campbell, G.S.; Norman, J. An introduction to Environmental Biophysics; Springer Science \& Business Media: Berlin/Heidelberg, Germany, 2012. [CrossRef]

54. Strzałka, K.; Kostecka-Gugała, A.; Latowski, D. Carotenoids and environmental stress in plants: Significance of carotenoidmediated modulation of membrane physical properties. Russ. J. Plant Physiol. 2003, 50, 168-173. [CrossRef]

55. Abdolmaleki, P.; Ghanati, F.; Sahebjamei, H.; Sarvestani, A.S. Peroxidase activity, lignification and promotion of cell death in tobacco cells exposed to static magnetic field. Environmentalist 2007, 27, 435-440. [CrossRef]

56. Racuciu, M.; Creanga, D.; Amoraritei, C. Biochemical changes induced by low frequency magnetic field exposure of vegetal organisms. Rom. J. Phys. 2007, 52, 601-606. Available online: https://rjp.nipne.ro/2007_52_5-6/0645_0652.pdf (accessed on 13 March 2021).

57. Racuciu, M.; Creanga, D.; Galugaru, C. The influence of extremely low frequency magnetic field on tree seedlings. Rom. J. Phys. 2008, 35, 337-342. Available online: https:/ /rjp.nipne.ro/2008_53_1-2/0361_0368.pdf (accessed on 13 March 2021).

58. Taia, W.K.; Kotbi, A.M.; AlZahrani, H.S. The effect of static magnetic forces on water contents and photosynthetic pigments in sweet basil Ocimum basilicum L. (Lamiaceae). Saudi J. Biol. Sci. 2007, 14, 103-107. Available online: https://inis.iaea.org/search/ searchsinglerecord.aspx?recordsFor=SingleRecord\&RN=40087321 (accessed on 6 March 2021). 
59. Strasser, R.J.; Tsimilli-Michael, M.; Srivastava, A. Analysis of the chlorophyll a fluorescence transient. In Chlorophyll a Fluorescence; Springer: Berlin/Heidelberg, Germany, 2004; pp. 321-362. [CrossRef]

60. Schreiber, U.; Bilger, W.; Neubauer, C. Chlorophyll fluorescence as a nonintrusive indicator for rapid assessment of in vivo photosynthesis. In Ecophysiology of Photosynthesis; Springer: Berlin/Heidelberg, Germany, 1995; pp. 49-70. [CrossRef]

61. Tsimilli-Michael, M.; Strasser, R.J. The energy flux theory 35 years later: Formulations and applications. Photosynth. Res. 2013, 117, 289-320. [CrossRef]

62. Deamici, K.M.; Cuellar-Bermudez, S.P.; Muylaert, K.; Santos, L.O.; Costa, J.A.V. Quantum yield alterations due to the static magnetic fields action on Arthrospira platensis SAG 21.99: Evaluation of photosystem activity. Bioresour. Technol. 2019, $292,121945$. [CrossRef] [PubMed]

63. Markou, G.; Muylaert, K. Effect of light intensity on the degree of ammonia toxicity on PSII activity of Arthrospira platensis and Chlorella vulgaris. Bioresour. Technol. 2016, 216, 453-461. [CrossRef] [PubMed]

64. Benavides, A.M.S.; Ranglová, K.; Malapascua, J.R.; Masojídek, J.; Torzillo, G. Diurnal changes of photosynthesis and growth of Arthrospira platensis cultured in a thin-layer cascade and an open pond. Algal Res. 2017, 28, 48-56. [CrossRef]

65. Voznyak, V.M.; Ganago, I.B.; Moskalenko, A.A.; Elfimov, E.I. Magnetic field-induced fluorescence changes in chlorophyll-proteins enriched with P-700. Biochim. Biophys. Acta (BBA)-Bioenerg. 1980, 592, 364-368. [CrossRef]

66. Schansker, G.; Tóth, S.Z.; Strasser, R.J. Dark recovery of the Chl a fluorescence transient (OJIP) after light adaptation: The qT-component of non-photochemical quenching is related to an activated photosystem I acceptor side. Biochim. Biophys. Acta (BBA)-Bioenerg. 2006, 1757, 787-797. [CrossRef]

67. Stirbet, A.; Lazár, D.; Kromdijk, J. Chlorophyll a fluorescence induction: Can just a one-second measurement be used to quantify abiotic stress responses? Photosynthetica 2018, 56, 86-104. [CrossRef]

68. Ripley, B.S.; Redfern, S.P.; Dames, J. Quantification of the photosynthetic performance of phosphorus-deficient Sorghum by means of chlorophyll-a fluorescence kinetics. S. Afr. J. Sci. 2004, 100, 615-618. Available online: https://hdl.handle.net/10520/EJC96177 (accessed on 2 March 2021).

69. Kataria, S.; Jain, M. Magnetopriming Alleviates Adverse Effects of Abiotic Stresses in Plants. In Plant Tolerance to Environmental Stress; CRC Press: Boca Raton, FL, USA, 2019; pp. 427-442. [CrossRef]

70. Maurino, V.G.; Weber, A.P. Engineering photosynthesis in plants and synthetic microorganisms. J. Exp. Bot. 2013, 64, 743-751. [CrossRef] [PubMed]

71. Smith, A.D.; Datta, S.P.; Smith, G.H. Oxford Dictionary of Biochemistry and Molecular Biology; Oxford University Press: Oxford, UK, 1997.

72. Zhao, B.; Su, Y. Process effect of microalgal-carbon dioxide fixation and biomass production: A review. Renew. Sustain. Energy Rev. 2014, 31, 121-132. [CrossRef]

73. Calvin, M. Forty years of photosynthesis and related activities. Photosynth. Res. 1989, 21, 3-16. [CrossRef] [PubMed]

74. Iverson, T.M. Evolution and unique bioenergetic mechanisms in oxygenic photosynthesis. Curr. Opin. Chem. Biol. 2006, 10, 91-100. [CrossRef] [PubMed]

75. Červený, J.; Šetlík, I.; Trtílek, M.; Nedbal, L. Photobioreactor for cultivation and real-time, in-situ measurement of $\mathrm{O}_{2}$ and $\mathrm{CO}_{2}$ exchange rates, growth dynamics, and of chlorophyll fluorescence emission of photoautotrophic microorganisms. Eng. Life Sci. 2009, 9, 247-253. [CrossRef]

76. Vian, A.; Davies, E.; Gendraud, M.; Bonnet, P. Plant responses to high frequency electromagnetic fields. BioMed Res. Int. 2016, 2016, 1830262. [CrossRef]

77. Deamici, K.M.; Santos, L.O.; Costa, J.A.V. Magnetic field as promoter of growth in outdoor and indoor assays of Chlorella fusca. Bioprocess Biosyst. Eng. 2021, 44, 1453-1460. [CrossRef]

78. Krylov, A.; Tarakonova, G.A. Plant physiology. Fiziol. Rost. 1960, 7, 156.

79. Martinez, E.; Carbonell, M.V.; Amaya, J.M. A static magnetic field of $125 \mathrm{mT}$ stimulates the initial growth stages of barley (Hordeum vulgare L.). Electro- Magn. 2000, 19, 271-277. [CrossRef]

80. Kataria, S.; Baghel, L.; Guruprasad, K.N. Effect of seed pretreatment by magnetic field on the sensitivity of maize seedlings to ambient ultraviolet radiation (280-400 nm). Int. J. Trop. Agric. 2015, 33, 3645-3652. Available online: https:/ / www.cabdirect.org/ cabdirect/abstract/20173067937 (accessed on 2 March 2020).

81. Pittman, U. Magnetism and plant growth: I effect on germination and early growth of cereal seeds. Can. J. Plant Sci. 1963, 43, 513-518. [CrossRef]

82. Galland, P.; Pazur, A. Magnetoreception in plants. J. Plant Res. 2005, 118, 371-389. [CrossRef]

83. Rathod, G.R.; Anand, A. Effect of seed magneto-priming on growth, yield and Na/K ratio in wheat (Triticum aestivum L.) under salt stress. Indian J. Plant Physiol. 2016, 21, 15-22. [CrossRef]

84. Long, S.P.; Zhu, X.G.; Naidu, S.L.; Ort, D.R. Can improvement in photosynthesis increase crop yields? Plant Cell Environ. 2006, 29, 315-330. [CrossRef] [PubMed]

85. Patel, P. Impact of Magneto-Priming of Seeds with Special Reference to Photosynthesis and Yield of Soybean and Maize. Ph.D Thesis, School of Life Sciences, Devi Ahilya Vishwavidyalaya, Indore, India, 2020.

86. Mathan, J.; Bhattacharya, J.; Ranjan, A. Enhancing crop yield by optimizing plant developmental features. Development 2016, 143, 3283-3294. [CrossRef] [PubMed] 
87. Fatima, A.; Kataria, S.; Baghel, L.; Guruprasad, K.; Agrawal, A.; Singh, B.; Sarkar, P.; Shripathi, T.; Kashyap, Y. Synchrotron-based phase-sensitive imaging of leaves grown from magneto-primed seeds of soybean. J. Synchrotron Radiat. 2017, 24, 232-239. [CrossRef]

88. Fatima, A.; Kataria, S.; Agrawal, A.K.; Singh, B.; Kashyap, Y.; Jain, M.; Brestic, M.; Allakhverdiev, S.I.; Rastogi, A. Use of Synchrotron Phase-Sensitive Imaging for the Investigation of Magnetopriming and Solar UV-Exclusion Impact on Soybean (Glycine max) Leaves. Cells 2021, 10, 1725. [CrossRef]

89. Afzal, I.; Noor, M.; Bakhtavar, M.; Ahmad, A.; Haq, Z. Improvement of spring maize performance through physical and physiological seed enhancements. Seed Sci. Technol. 2015, 43, 238-249. [CrossRef]

90. Gupta, M.K.; Anand, A.; Paul, V.; Dahuja, A.; Singh, A. Reactive oxygen species mediated improvement in vigour of static and pulsed magneto-primed cherry tomato seeds. Indian J. Plant Physiol. 2015, 20, 197-204. [CrossRef]

91. Raipuria, R.K.; Kataria, S.; Watts, A.; Jain, M. Magneto-priming promotes nitric oxide via nitric oxide synthase to ameliorate the UV-B stress during germination of soybean seedlings. J. Photochem. Photobiol. B Biol. 2021, 220, 112211. [CrossRef] [PubMed]

92. Thomas, S.; Ramakrishnan, R.S.; Anand, A. Growth, Na+/K+ Partitioning and Yield of Chickpea Plants Alleviated From Salt Stress by Magnetopriming. Int. J. Curr. Microbiol. Appl. Sci. 2019, 8, 821-833. [CrossRef]

93. Maheshwari, B.L.; Grewal, H.S. Magnetic treatment of irrigation water: Its effects on vegetable crop yield and water productivity. Agric. Water Manag. 2009, 96, 1229-1236. [CrossRef] 